\title{
Inhibition of the urea-urease reaction by the components of the zeolite imidazole frameworks- 8 and the formation of urease-zinc-imidazole hybrid compound
}

\author{
Norbert Német $^{1}$ - Ylenia Miele ${ }^{2} \cdot$ Gábor Shuszter $^{3}$ (D) Eszter L. Tóth ${ }^{1}$. \\ János Endre Maróti ${ }^{4} \cdot$ Péter János Szabó $^{4} \cdot$ Federico Rossi $^{5}$ (I) István Lagzi ${ }^{1,6}$ (D)
}

Received: 13 October 2021 / Accepted: 13 December 2021 / Published online: 7 January 2022

(c) The Author(s) 2022

\begin{abstract}
In the past decade, much effort has been devoted to using chemical clock-type reactions in material design and driving the self-assembly of various building blocks. Urea-urease enzymatic reaction has chemical $\mathrm{pH}$ clock behavior in an unbuffered medium, in which the induction time and the final $\mathrm{pH}$ can be programmed by the concentrations of the reagents. The urea-urease reaction can offer a new alternative in material synthesis, where the $\mathrm{pH}$ and its course in time are crucial factors in the synthesis. However, before using it in any synthesis method, it is important to investigate the possible effects of the reagents on the enzymatic reaction. Here we investigate the effect of the reagents of the zeolite imidazole framework- 8 (zinc ions and 2-methylimidazole) on the urea-urease reaction. We have chosen the zeolite imidazole framework- 8 because its formation serves as a model reaction for the formation of other metal-organic frameworks. We found that, besides the inhibition effect of the zinc ions which is well-known in the literature, 2-methylimidazole inhibits the enzymatic reaction as well. In addition to the observed inhibition effect, we report the formation of a hybrid urease-zinc-2-methylimidazole hybrid material. To support the inhibition effect, we developed a kinetic model which reproduced qualitatively the experimentally observed kinetic curves.
\end{abstract}

Keywords Clock reaction · Inhibition · Urea-urease reaction · Material design

\section{Introduction}

A clock reaction (or chemical clock) is a type of chemical reaction in which the product appears suddenly with a well-defined time lag after starting the reaction [1-3]. The lag time is also defined as Landolt time after the iodine clock reaction

István Lagzi

lagzi.istvan.laszlo@ttk.bme.hu

Extended author information available on the last page of the article 
discovered by Heinrich Landolt [4]. Strictly speaking, a clock reaction is a twostep process with the time scale separation of the reactions $(A+\ldots \rightarrow P+\ldots$ with slow kinetics, $\mathrm{B}+\mathrm{P} \rightarrow \ldots$ with fast kinetics and the initial concentration of A should be greater than that of the B) [2]. Chemical reactions with different kinetic and mechanistic features can also have an induction period, e.g., autocatalytic reactions $(\mathrm{A}+\mathrm{P} \rightarrow 2 \mathrm{P})$, consecutive reactions $(\mathrm{A} \rightarrow \mathrm{B} \rightarrow \mathrm{P})$ and enzymatic reactions.

In recent years, the application of systems exhibiting chemical clock type behavior in the material design and driving the self-assembly of various building blocks has gained much attention. A key engineering issue is that the clock time (induction period) and the final concentration of the product (e.g., $\mathrm{H}^{+}$) can be easily adjusted by the initial concentration of the reagents and experimental conditions (e.g., temperature) [5-9]. Predominantly reactions showing chemical clock type of behavior are based on reactive inorganic compounds (e.g., sulfite, bromate) and non-biocompatible reagents (e.g., formaldehyde). Due to this disadvantage, the application of these chemical clock-type systems involving bio-related components had been missing. Therefore, there was an increasing demand to develop biocompatible clock reactions to use in various bio-related applications. Enzymatic reactions can serve as possible candidates to overcome the previously mentioned drawbacks.

Because of their bell-shaped activity dependence on $\mathrm{pH}$, certain enzymatic reactions can produce chemical clock type behavior in unbuffered media, if one or more products of the reaction itself affect the $\mathrm{pH}$. One of the simplest systems showing such behavior is the hydrolysis of urea mediated by the enzyme urease to yield ammonia and carbon dioxide [10-12]. Urea-urease set was successfully employed for time programming of self-regulating supramolecular hydrogels [13, 14], spatiotemporal control of the gelation and polymerization fronts [15], layered compartmentalization [16] and vesicles self-division [17-19]. In material science, the ureaurease reaction can be further employed to control the formation process of those compounds which synthesis relies on $\mathrm{pH}$-sensitive precursors.

Metal-organic frameworks (MOFs) are unique porous crystalline materials having various applications in catalysis, gas storage and separation, electronics, chromatography, and drug delivery. [20-26] MOFs are usually produced by the coordination of metal cations and organic linkers in a liquid phase. The most common solvent in the solvothermal synthesis of MOFs is dimethylformamide (DMF). However, several protocols have been published on the generation of MOFs in the water phase. In this case, the strategy includes the application of the proper excess of the organic linkers and appropriately set $\mathrm{pH}$ to provide successful coordination to the metal cations [27-29].

Our ultimate goal is to use the bio-compatible urea-urease reaction in the synthesis of MOFs [30]. We hypothesize that the final $\mathrm{pH}$ and temporal change of the $\mathrm{pH}$ might significantly affect the morphology of the produced materials. However, before the design steps would be made it is crucial to investigate the effect of the reagents of MOFs on the kinetics of the enzymatic reaction. Here we investigate the effect of the components of the zeolite imidazole framework-8 (ZIF-8), zinc ions and 2-methylimidazole on the urea-urease reaction. We have chosen ZIF-8 because it serves as a model system for other MOFs and its formation has been extensively studied in the literature [31-36]. This type of investigation can be very important 
since metal cations (as one reagent of MOFs) acts as inhibitors in the most enzymatic reaction [37-39]. In addition to this, we report the formation of a hybrid urease-zinc-2-methylimidazole (U-Zn-Met) structure.

\section{Experimental}

Urea $\left(\mathrm{CO}\left(\mathrm{NH}_{2}\right)_{2}\right.$, Sigma), Urease enzyme from Canavalia ensiformis (Jack bean) (typically 40,150 units/g, Sigma-Aldrich), 2-methylimidazole (Sigma-Aldrich), zinc acetate dihydrate (Sigma-Aldrich), and acetic acid $\left(\mathrm{CH}_{3} \mathrm{COOH}\right.$, Sigma-Aldrich) were used as received without further purification. The aqueous solutions of all chemicals (except acetic acid solution) were freshly prepared before each measurement, and the urease stock solution was stored at $\sim{ }^{\circ} \mathrm{C}$.

Kinetic experiments without the turbidity measurements were carried out in an open water-jacketed glass cell $\left(V=22 \mathrm{~mL}, 20.0 \pm 0.2^{\circ} \mathrm{C}\right)$, and the $\mathrm{pH}$ was monitored by a glass microelectrode (Mettler Toledo). The solutions of the reactants (with a total reaction volume of $18 \mathrm{~mL}$ ) were consecutively added to the cell as follows: urea solution, 2-methylimidazole solution, acetic acid solution (to adjust the $\mathrm{pH}$ to $\sim$ ), zinc acetate solution, and urease solution. The reaction mixture was stirred by using a magnetic stirrer at $300 \mathrm{rpm}$.

Kinetic experiments with the turbidity measurements were carried out in a cuvette with $10 \mathrm{~cm}$ optical path length and $100 \mathrm{~mL}$ volume. The cuvette was thermostated at $20.0 \pm 0.2^{\circ} \mathrm{C}$ in a metal block with gaps for the light beam. The experimental procedure was similar to the kinetic experiments performed in a glass cell except that the turbidity was monitored by a UV-Vis spectrophotometer (VWR UV-1600PC) in kinetic mode $(\lambda=600 \mathrm{~nm})$ connected to PC (Fig. S1 in the Supplementary Information, SI).

The formed white precipitate was filtered by using a $0.45 \mu \mathrm{m}$ syringe filter (cellulose-acetate) and washed three times with $3 \mathrm{~mL}$ distilled water and once with $2 \mathrm{~mL}$ DMF. Then the filter was dried $(\sim 24 \mathrm{~h})$, and the white precipitate was removed from the surface of the filter. The microstructure of the dried samples was characterized by scanning electron microscopy (SEM), the sample was transferred to the carbon tape and sputter-coated with gold.

\section{Simulations}

Numerical simulations were run by solving the ordinary differential equations corresponding to the kinetics of the chemical reactions involved in the process.

The urea-urease reaction has the general stoichiometry

$$
\mathrm{CO}\left(\mathrm{NH}_{2}\right)_{2}+\mathrm{H}_{2} \mathrm{O} \stackrel{\text { urease }}{\longrightarrow} 2 \mathrm{NH}_{3}+\mathrm{CO}_{2}
$$

and the corresponding reaction rate is described by the Michaelis-Menten kinetics. 
(RE)

$$
R=\frac{v_{\text {max }}[\mathrm{S}]}{\left(K_{\mathrm{M}}+[\mathrm{S}]\left(1+\frac{[\mathrm{S}]}{K_{\mathrm{S}}}\right)\right)\left(1+\frac{[\mathrm{P}]}{K_{\mathrm{P}}}\right)\left(1+\frac{K_{\mathrm{es} 2}}{\left[\mathrm{H}^{+}\right]}+\frac{\left[\mathrm{H}^{+}\right]}{K_{\mathrm{es} 1}}\right)},
$$

Here $v_{\max }=k_{1}[\mathrm{E}]$, with [E] expressed as enzyme activity (units $/ \mathrm{mL}$ ), $K_{\mathrm{M}}$ is the Michaelis constant, $K_{\mathrm{es} 1}$ and $K_{\mathrm{es} 2}$ are protonation equilibrium constants of the substrate-enzyme complex. $K_{\mathrm{es} 2}$ accounts for the dependence of the rate on the formation of an active protonated form of the enzyme-substrate complex (ESH, $\mathrm{S}$ is the substrate and EH the enzyme) and $K_{\text {es } 1}$ for the formation of an inactive biprotonated form $\left(\mathrm{ESH}^{2+}\right)$. [P] is the concentration of the protonated form of ammonia $\left(\mathrm{NH}_{4}^{+}\right),[\mathrm{S}]$ is the concentration of urea, and $K_{\mathrm{S}}$ and $K_{\mathrm{P}}$ are the equilibrium constants for uncompetitive substrate and product inhibition, respectively. The $\mathrm{pH}$ is governed by the following equilibria

$$
\begin{aligned}
& \mathrm{NH}_{4} \underset{k_{2 \mathrm{r}}}{\stackrel{k_{2}}{\rightleftarrows}} \mathrm{NH}_{3}+\mathrm{H}^{+} \\
& \mathrm{CO}_{2}+\mathrm{H}_{2} \mathrm{O} \underset{k_{3 \mathrm{r}}}{\stackrel{k_{3}}{\rightleftarrows}} \mathrm{H}^{+}+\mathrm{HCO}_{3}^{-} \\
& \mathrm{HCO}_{3}{ }^{-} \underset{k_{4 \mathrm{r}}}{\stackrel{k_{4}}{\rightleftarrows}} \mathrm{CO}_{3}{ }^{2-}+\mathrm{H}^{+} \\
& \mathrm{H}_{2} \mathrm{O} \underset{k_{5 \mathrm{r}}}{\stackrel{k_{5}}{\rightleftarrows}} \mathrm{H}^{+}+\mathrm{OH}^{-} \\
& \mathrm{HA} \underset{k_{\sigma_{\mathrm{r}}}}{\stackrel{k_{6}}{\rightleftarrows}} \mathrm{A}^{-}+\mathrm{H}^{+} \\
& \mathrm{MIMH}_{2}+\underset{k_{\tau_{\mathrm{r}}}}{\stackrel{k_{7}}{\rightleftarrows}} \mathrm{MIMH}+\mathrm{H}^{+} \\
& \mathrm{MIMH} \underset{k_{8 \mathrm{r}}}{\stackrel{k_{8}}{\rightleftarrows}} \mathrm{MIM}^{-}+\mathrm{H}^{+}
\end{aligned}
$$

Here HA is acetic acid, MIMH is 2-methylimidazole, $\mathrm{MIMH}_{2}{ }^{+}$is the protonated form of MIMH and MIM${ }^{-}$is the deprotonated form. When $\mathrm{Zn}^{2+}$ is added to the solution, several species can be generated according to the following equilibria

$$
\begin{aligned}
& \mathrm{Zn}^{2+}+\mathrm{CO}_{3}{ }^{2-} \underset{k_{9 \mathrm{r}}}{\stackrel{k_{9}}{\rightleftarrows}} \mathrm{ZnCO}_{3} \\
& \mathrm{Zn}^{2+}+\mathrm{OH}^{-} \underset{k_{10 \mathrm{r}}}{\stackrel{k_{10}}{\rightleftarrows}} \mathrm{Zn}(\mathrm{OH})^{+} \\
& \mathrm{Zn}(\mathrm{OH})^{+}+\mathrm{OH}^{-} \underset{k_{11 \mathrm{r}}}{\stackrel{k_{11}}{\rightleftarrows}} \mathrm{Zn}(\mathrm{OH})_{2} \\
& \mathrm{Zn}(\mathrm{OH})_{2}+\mathrm{OH}^{-} \underset{k_{12 \mathrm{r}}}{\stackrel{k_{12}}{\rightleftarrows}} \mathrm{Zn}(\mathrm{OH})_{3}{ }^{-} \\
& \mathrm{Zn}(\mathrm{OH})_{3}{ }^{-}+\mathrm{OH}^{-} \underset{k_{13 \mathrm{r}}}{\stackrel{k_{13}}{\rightleftarrows}} \mathrm{Zn}(\mathrm{OH})_{4}{ }^{2-} \\
& \mathrm{Zn}^{2+}+2 \mathrm{MIM}^{-} \underset{k_{14 r}}{\stackrel{k_{14}}{\rightleftarrows}} \mathrm{Zn}(\mathrm{MIM})_{2}
\end{aligned}
$$

The set of ordinary differential equations derived from the reaction rates (reported in the SI) was numerically integrated by using the software XPPAUT [40] and COPASI [41] with the parameters listed in Tables S1-S3 in the SI. 


\section{Results and discussion}

The urea-urease reaction yields carbon dioxide and ammonia (Eq. 1) and since stoichiometrically twice ammonia is produced than carbon dioxide, the $\mathrm{pH}$ continuously increases in an unbuffered medium [42]. In experiments, the initial $\mathrm{pH}$ of the reaction mixture was set to $\mathrm{pH} \sim 4$ by acetic acid, and due to the bell-shaped activity dependence of the enzyme on $\mathrm{pH}$ (having a maximum at $\mathrm{pH}=8.2$ [12]) a sigmoidal kinetic curve ( $\mathrm{pH}$ versus time) can be obtained. Figure 1a shows typical kinetic curves obtained in the urea-urease enzymatic reaction, it can be seen that the clock time ranges between $\sim 30$ and $\sim 200 \mathrm{~s}$ in the excess substrate (urea) depending on the enzyme concentration. The inhibition effect of metal cations (especially zinc ions) on the urea-urease reaction is known and thoroughly explored [43-45], therefore, we did not investigate it in this study. On the other hand, no studies have been conducted on the effect of 2-methylimidazole on urease enzyme activity. Figures $1 \mathrm{~b}$ and $\mathrm{S} 2$ show that the 2-methylimidazole significantly affects the enzymatic reaction. The activity of the enzyme was found to decrease up to $70 \%$ when the concentration of the 2-methylimidazole was $100 \mathrm{mM}$ (Fig. S2 in the SI), consequently the clock time increased, and it was found to be between 1000 and $3500 \mathrm{~s}$ at a fixed concentration of 2-methylimidazole $(30.0 \mathrm{mM})$. The inhibition effect by the zinc ions and 2-methylimidazole can be explained by considering the same framework. In fact, the urease is a nickel-containing metalloenzyme, therefore, $\mathrm{Zn}^{2+}$ ions compete with $\mathrm{Ni}^{2+}$ in coordinating the protein groups thus changing the original enzymatic structure and affecting the activity. Since 2-methylimidazole coordinates with zinc ions (as a product of the ZIF-8), we can speculate a competition with protein groups to coordinate the nickel in the enzyme. Similarly, this coordination can affect the original active site geometry thus decreasing the enzyme activity.

First, we explored the cumulative inhibition effect of the reagents of the ZIF-8, and due to their pronounced effect on the urease activity, we carried out our kinetic investigation at low concentrations of zinc ions $(1.0 \mathrm{mM})$ and 2-methylimidazole
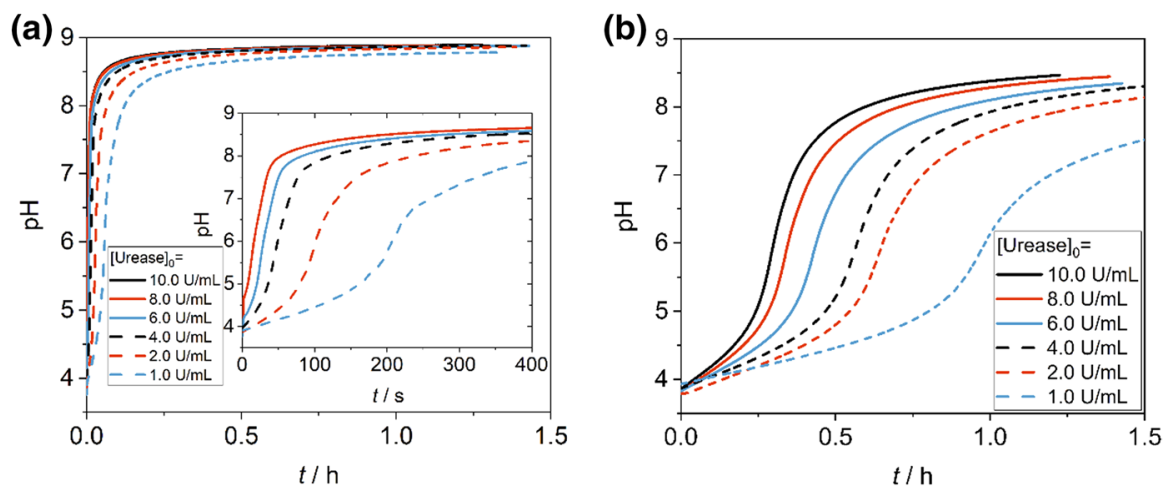

Fig. 1 pH kinetic curves of the urea-urease clock reactions with different enzyme concentrations in a batch reactor in the absence $\left([2-\text { methylimidazole }]_{0}=0.0 \mathrm{mM}\right)(\mathbf{a})$ and the presence of 2-methylimidazole $\left([2 \text {-methylimidazole }]_{0}=30.0 \mathrm{mM}\right), \mathbf{b}[\text { urea }]_{0}=390 \mathrm{mM}$ and $\left[\mathrm{CH}_{3} \mathrm{COOH}\right]_{0}=80.9 \mathrm{mM}$. The curves corresponding to 10.0 and $8.0 \mathrm{U} \mathrm{mL}^{-1}$ are overlapped in the inset 
(4.0 $\mathrm{mM}$ ) keeping only a slight excess of the organic linker. In these kinetic experiments, we recorded both the turbidity of the solution and the $\mathrm{pH}$ course. Fig. $2 \mathrm{a}, \mathrm{b}$ show the kinetic curves ( $\mathrm{pH}$ vs time) and Fig. 2c, d show variation of the turbidity in time in the case of fixed substrate concentration while the concentration of the enzyme was varied, and vice versa, when the enzyme concentration was fixed the urea concentration was changed. It can be seen that by increasing both the substrate and the enzyme concentrations the clock time (the interval between the start of the experiment and the time at which the rate of the $\mathrm{pH}$ change is maximum) is reduced. The enzyme concentration affects the final $\mathrm{pH}$ of the systems at the excess of the urea.

In all the experiments, when the $\mathrm{pH}$ reached $\sim 6.4$, a white precipitate appeared in the solution causing an increase of turbidity as shown in Fig. 2c and d. After reaching the maximum value, the turbidity decreased in time due to the formation of bigger aggregates. We carried out several control experiments to investigate the origin of the precipitation phenomenon. First, we titrated a solution of zinc ions $\left(\left[\mathrm{Zn}^{2+}\right]_{0}=1.0 \mathrm{mM}\right)$ with the sodium hydroxide solution starting from $\mathrm{pH} \sim 4$ similarly to the experiments with the enzyme, substrate, and linker. Zinc hydroxide appeared in the solution at $\mathrm{pH}=7.34$ indicating that the white precipitate cannot
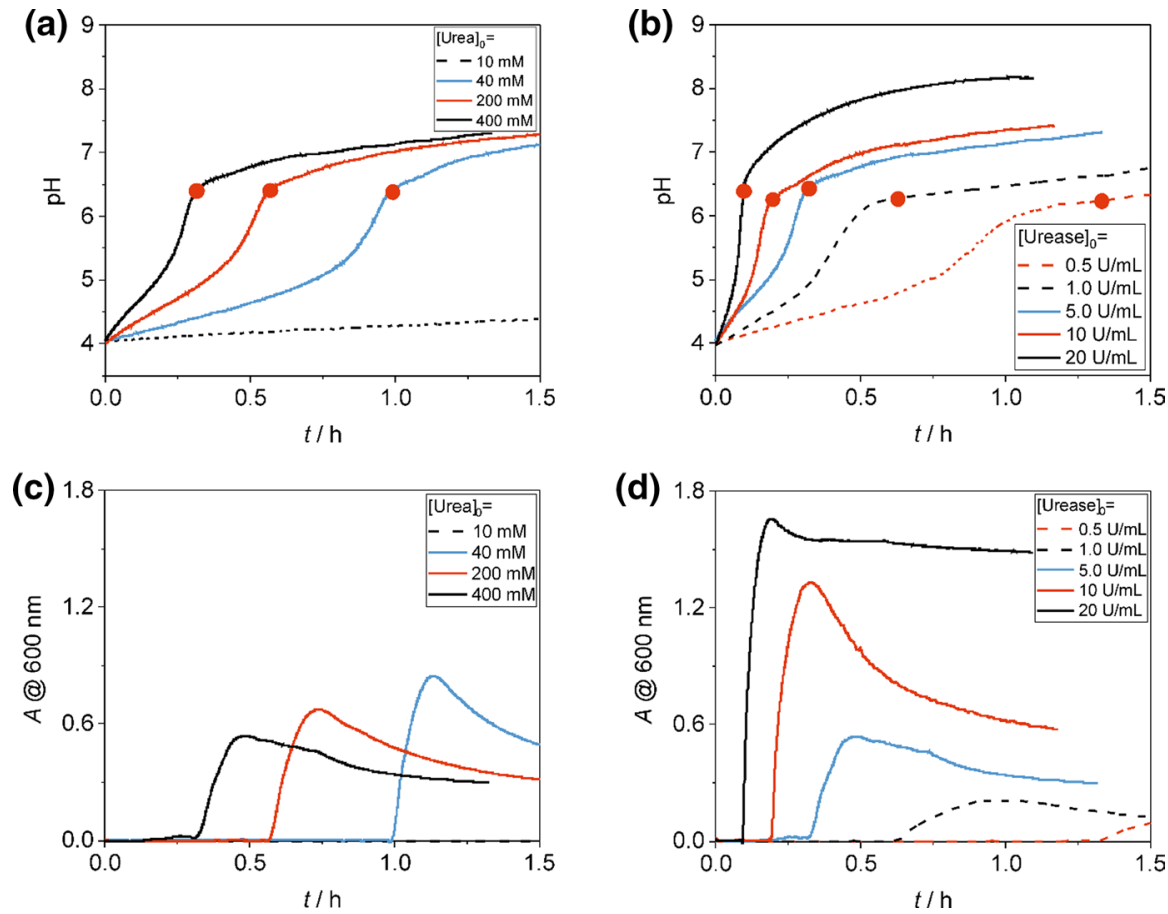

Fig. 2 Urea-urease reactions in the presence of $\left[\mathrm{Zn}^{2+}\right]=1 \mathrm{mM}$ and [2-methyl imidazole] $=4 \mathrm{mM}$ with different urea (a) and (c) (where $\left.[\text { urease }]_{0}=5 \mathrm{Unit} / \mathrm{mL}\right)$ and urease $(\mathbf{b})$ and (d) (where $\left.[\text { urea }]_{0}=400 \mathrm{mM}\right)$ concentrations. The initial $\mathrm{pH}$ was set to 4 with an acetic acid solution. Red dots show when the turbidity started to increase from zero 
be the zinc hydroxide because in most cases in the enzymatic reaction the final $\mathrm{pH}$ could not reach this value (Fig. S3a in the SI). Second round of the control experiments was the titration of a solution having zinc ions, 2-methylimidazole, and urease (in the absence of urea) with the sodium hydroxide solution starting from $\mathrm{pH} \sim 4$ $\left.\left(\left[\mathrm{Zn}^{2+}\right]_{0}=1.0 \mathrm{mM},[2 \text {-methylimidazole }]_{0}=4.0 \mathrm{mM} \text {, and [urease }\right]_{0}=10.0 \mathrm{U} / \mathrm{mL}\right) . \mathrm{In}$ this case, we detected a turbidity change in the solution at $\mathrm{pH}=6.07$ (Fig. S3b in the SI). In the third setup, we titrated a solution having zinc ions, 2-methylimidazole, and urea (in the absence of urease) and observed no precipitation $\left(\left[\mathrm{Zn}^{2+}\right]_{0}=1.0 \mathrm{mM}\right.$, $[2 \text {-methylimidazole }]_{0}=4.0 \mathrm{mM}$, and urea $_{0}=4.0 \mathrm{mM}$, Fig. S3c in the SI). We then hypothesized that the origin of the precipitation event could be attributed to the interaction of zinc ions with the enzyme. Therefore, we carried out control experiments titrating a solution of zinc ions and enzyme with the sodium hydroxide solution $\left.\left(\left[\mathrm{Zn}^{2+}\right]_{0}=1.0 \mathrm{mM} \text { and [urease }\right]_{0}=10.0 \mathrm{U} / \mathrm{mL}\right)$. We observed the formation of a white precipitate accompanied by the increase of the turbidity at $\mathrm{pH}=6.08$ (Fig. $\mathrm{S} 3 \mathrm{~d}$ in the SI). Based on these control experiments, we could rule out the formation of either zinc hydroxide or ZIF-8 because the generated increase of $\mathrm{pH}$ was not high enough to facilitate their formation. However, we observed the precipitation of zinc ions with urease.

Numerical simulations can help to understand the behavior of urease in the presence of the ZIF-8 reactants. Figure 3 reports the integration of the ordinary differential equations describing the chemical equilibria (RE) and (R1)-(R7), in the presence and the absence of 2-methylimidazole. Figure 3 a shows an excellent matching of the model with the experimental behavior of the urea hydrolysis in the absence of 2-methylimidazole when different amounts of the enzyme are added to the solution (integration parameters and kinetic constants are reported in Table S1 of the SI). To introduce the inhibitory effect of 2-methylimidazole, the kinetic constants $K_{\text {es1 }}$ and $K_{\text {es2 }}$, accounting for the $\mathrm{pH}$ dependency of the enzyme activity, were


Fig. 3 Results of the numerical simulations of the urea-urease system. a Kinetic curves in the absence of 2-methylimidazole ([2-methylimidazole $]_{0}=0 \mathrm{mM}$ ) and comparison with the experimental results; dotted lines correspond to the simulations. b Simulated clock time in the presence of 2-methylimidazole ([2-methylimidazole $\left.]_{0}=30.0 \mathrm{mM}\right)$, the inset reports an example of simulated curve when $[\mathrm{E}]_{0}=8 \mathrm{U} / \mathrm{mL}$, [urea $]_{0}=390 \mathrm{mM}$, and $\left[\mathrm{CH}_{3} \mathrm{COOH}\right]_{0}=80.9 \mathrm{mM}$; solid and dotted lines corresponds to the experimental and numerical results, respectively. Kinetic constants and simulation parameters are reported in the SI 
slightly decreased, while $K_{\mathrm{P}}$, accounting for the non-competitive product inhibition, was increased (see details in Table S2 in the SI). Moreover, the basic character of 2-methylimidazole affects the final $\mathrm{pH}$ of the solution, as described by equilibria (R6) and (R7). As an example, the inset in Fig. 3b shows that the sigmoidal shape of the enzymatic reaction ([urea $]_{0}=390 \mathrm{mM},\left[\mathrm{CH}_{3} \mathrm{COOH}\right]_{0}=80.9 \mathrm{mM},[\mathrm{E}]_{0}=8$ $\mathrm{U} / \mathrm{mL}$, [2-methylimidazole $]_{0}=30.0 \mathrm{mM}$ ) is well described by the modified model, though with some deviations in the autocatalytic part and the trend of both the clock time (Fig. 3b) and the final $\mathrm{pH}$ of the solution (Fig. S4 in SI) at increasing $[\mathrm{E}]_{0}$ is reproduced with a quantitative matching at high enzyme concentration.

When the zinc is added to the solution, additional chemical equilibria R8-R13 were included in the model through the corresponding kinetics (constants and parameters reported in Table S3 in the SI), but we could reproduce the general trends reported in Fig. 2 only by drastically changing the enzymatic kinetic constants and the concentration of some reactants. A possible explanation for the mismatch between experimental conditions and model parameters can be found in the formation of the precipitate, which can have multiple effects on global dynamics. As previously mentioned, $\mathrm{Zn}^{2+}$ itself is a strong inhibitor for the enzyme, in addition to this, when the enzyme is embedded in the precipitate, the diffusion of the substrate towards the active sites is strongly hindered. The net result would be that the real concentration of reactive urea is much lower than the theoretical one, as it happens when urease is loaded on resin particles [12]. In amino resin particles, the bell shape is shifted to lower $\mathrm{pH}$ values and the stability of the enzyme is increased. The values of $K_{\mathrm{es} 1}, K_{\mathrm{es} 2}$ and $K_{\mathrm{p}}$ change due to electrostatic interactions between the enzyme and the amino groups of the resin. Similarly, in our system, we observe a shift of the maximum activity towards lower pHs. This shift can depend on the interactions between $\mathrm{Zn}^{2+}$ and 2-methylimidazole with $\mathrm{Ni}^{2+}$ ions and the amino acids of the active site of urease.

At present we do not have enough data to account for reliable values of the kinetics constants, however, Fig. 4 shows that the experimental trend reported in Fig. 2b of the final $\mathrm{pH}$ (Fig. 4a) and of the clock time (Fig. 4b) with respect to the variation
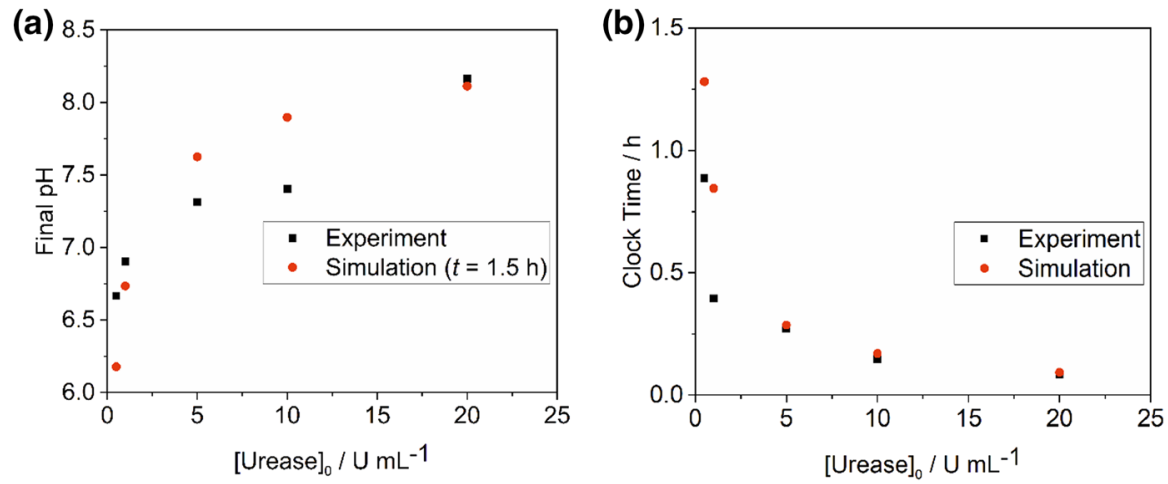

Fig. 4 Simulated final $\mathrm{pH}$ (a) and simulated clock time (b) for a system containing $\left[\mathrm{Zn}^{2+}\right]=1 \mathrm{mM}$, $[2$-methyl imidazole $]=4 \mathrm{mM}$, $[\mathrm{Urea}]_{0}=400 \mathrm{mM}$ and $[\mathrm{HA}]=1 \mathrm{mM}$ for different $[\text { Urease }]_{0}$ 
of $[\mathrm{E}]_{0}$ can be simulated by decreasing of 2 orders of magnitude $K_{\mathrm{es} 1}$ and increasing $K_{\text {es } 2}$ of 3 orders of magnitude. In contrast, data reported in Fig. 2a cannot be reproduced by our model, unless the concentrations of urea are decreased by 2 orders of magnitude.

To characterize the morphology of the precipitates, we performed scanning electron microscopy (SEM) measurements, and to increase the amount of the precipitate in experiments, we increased the concentration of zinc ions to $3.0 \mathrm{mM}$, but the ratio of the concentrations of the cation and linker remained 1:4. In the enzymatic reaction in the presence of zinc ions and linker, we obtained highly monodisperse spherical particles with an average size and polydispersity index (PDI) of $0.82 \mu \mathrm{m}$ and 0.026, respectively (Fig. 5a). This morphology significantly differs from the crystal structures of the $\mathrm{Zn}^{2+}$-enzyme compound (Fig. 5b-plate-like structure) and ZIF-8 crystals (Fig. 5c-dodecahedra). We exclude the encapsulation of the enzyme by ZIF-8 because, in this case, the morphology of the MOF crystals remained intact [46-48]. We hypothesize the following mechanism for the formation of the U-ZnMet structure. When the $\mathrm{pH}$ increases driven by the urea-urease reaction, first the $\mathrm{Zn}^{2+}$-enzyme compound is formed, which acts as heterogeneous nuclei for the further coprecipitation of the enzyme, $\mathrm{Zn}^{2+}$, and 2-methylimidazole even in the $\mathrm{pH}$ range where no pure ZIF-8 formation is expected.

It should be noted that we cannot rule out the formation of zinc carbonate since the enzymatic system generates carbon dioxide which transforms into carbonate ions at alkaline conditions. Metal cations can react with carbonate ions producing carbonate precipitate. This strategy has been used in the remediation of heavy metals [49]. To investigate the formation of zinc carbonate, we carried out a control experiment in which zinc ions were titrated by a concentrated carbonate solution (Fig. S5 in the SI). We found that the zinc carbonate started to precipitate at $\mathrm{pH} \sim 7.2$, which is higher than the $\mathrm{pH}$ for the appearance of the precipitate in the system $(\mathrm{pH} \sim 6.4$, Fig. 2a and $b$ ). In other words, the observed precipitation is not due to the formation of the zinc carbonate.

We investigated the enzymatic activity of the formed precipitate (see the protocol in the SI). After each cycle, the U-Zn-Met was filtered, washed three times with distilled water, and redispersed in a liquid phase. Figure 6 shows that the activity of this hybrid compound gradually decreased until the third cycle in which the sample practically lost its enzymatic activity, which can be attributed to the disintegration of the structure.

\section{Conclusions}

In this study, we investigated the inhibition of 2-methylimidazole and the components of the ZIF-8 (zinc ions and 2-methylimidazole) in the urea-urease enzymatic reaction. We found that not only the zinc ions inhibit the reaction, but 2-methylimidazole does the same. Using the urea-urease enzymatic reaction, in the presence of the zinc cations and linker, we could not achieve the formation of ZIF-8 crystals due to the lower $\mathrm{pH}$ increase in the inhibited enzymatic reaction. We observed the formation of a hybrid U-Zn-Met material with a strong 


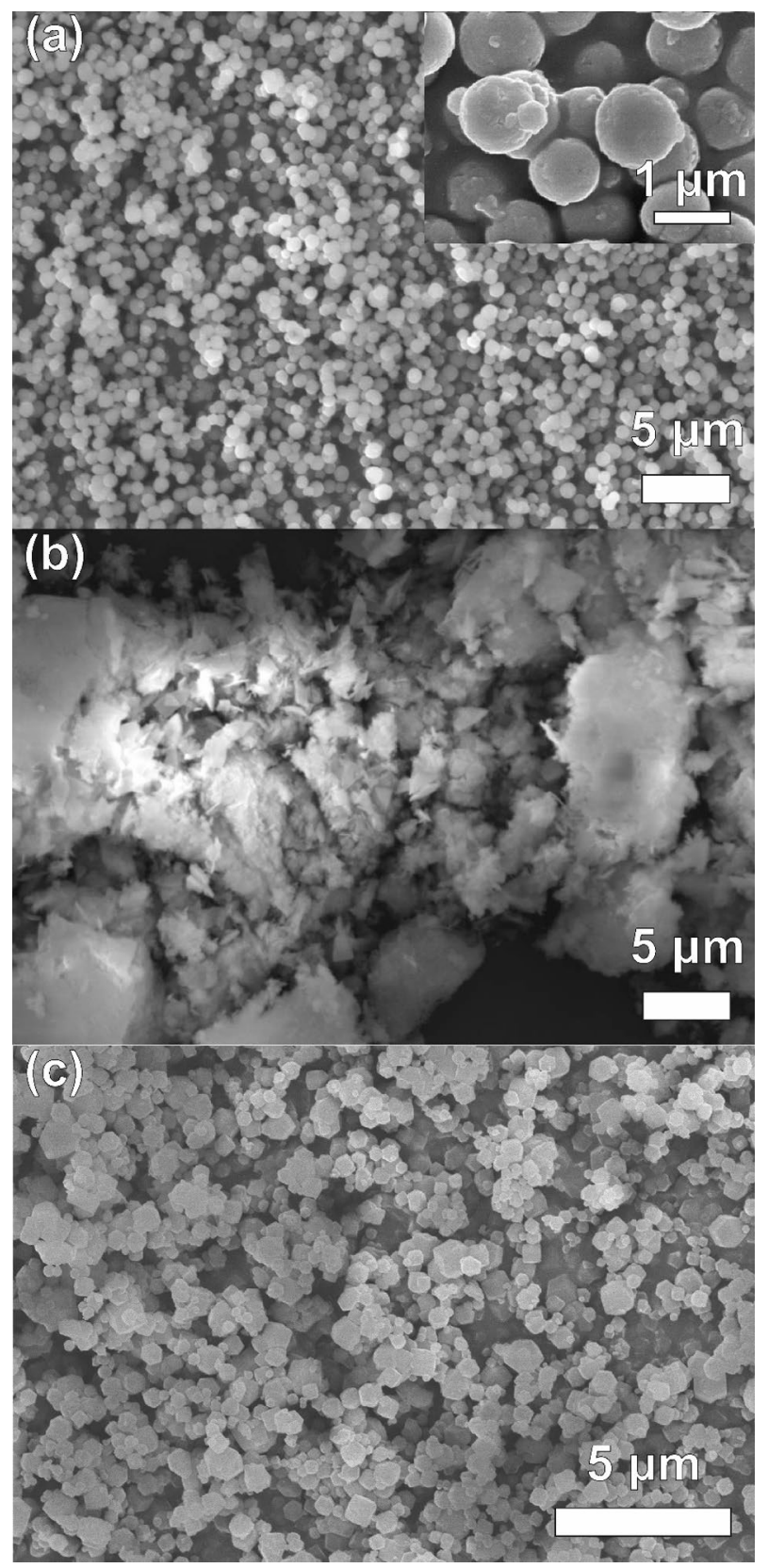

Fig. 5 SEM micrographs of precipitates formed in the urea-urease enzymatic reaction in the presence of the zinc ions and linker $\left(\left[\mathrm{Zn}^{2+}\right]_{0}=3.0 \mathrm{mM} \text {. [2-methylimidazole }\right]_{0}=12.0 \mathrm{mM}$, [urea $]_{0}=390 \mathrm{mM}$, and [urease $\left.]_{0}=10.0 \mathrm{U} / \mathrm{mL}\right)(\mathbf{a})$; zinc-urease crystals formed in the titration experiment with the solution of sodium hydroxide $\left.\left(\left[\mathrm{Zn}^{2+}\right]_{0}=3.0 \mathrm{mM} \text {. and [urease }\right]_{0}=10.0 \mathrm{U} / \mathrm{mL}\right)(\mathbf{b}) ; \mathrm{ZIF}-8$ crystals in the direct reaction of zinc ions and linker $\left.\left(\left[\mathrm{Zn}^{2+}\right]_{0}=3.0 \mathrm{mM} \text {. [2-methylimidazole }\right]_{0}=12.0 \mathrm{mM}\right)(\mathbf{c})$ 
Fig. 6 Activity of the synthesized U-Zn-Met in several cycles. 0 corresponds to the initial activity of the U-Zn-Met calculated based on the concentration of the urease used

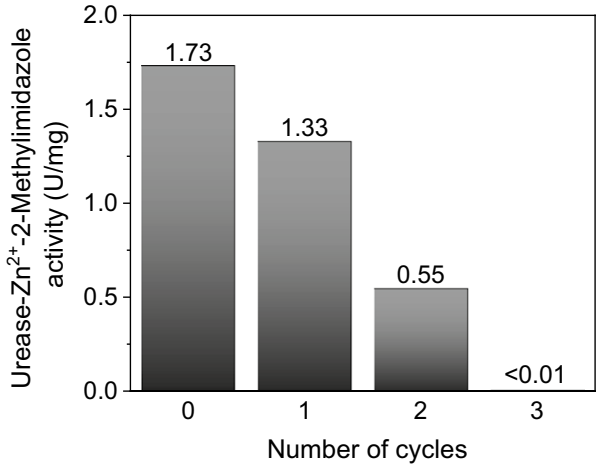

interaction between urease and the MOF reactants, $\mathrm{Zn}^{2+}$ and 2-methylimidazole, which was confirmed from the kinetic simulations. The kinetic model includes the $\mathrm{pH}$ equilibria, the enzymatic constants of the urea-urease system and the equilibria coming from the $\mathrm{Zn}^{2+}$ ions. The equilibria correlated to the formation of various zinc hydroxides, the precipitation of $\mathrm{Zn}$ carbonate and the ZIF formation (at $\mathrm{pH}$ higher than 10) do not affect significantly the final $\mathrm{pH}$ and the induction period for a wide range of values (even six orders of magnitude). The change of some enzymatic parameters $\left(K_{\mathrm{es} 1}, K_{\mathrm{es} 2}\right.$ and $\left.K_{\mathrm{p}}\right)$ leads to a shift of the bell shape towards acidic pHs and better reproduces the experimental data (e.g., the sigmoidal shape with a low final $\mathrm{pH}$ ). This trend is in line with the kinetic activity of other immobilized enzymes which are more stable and work even at lower $\mathrm{pH}$ values compared to the free enzyme. In future research, our aim would be to characterize this hybrid structure and understand if other chemical species of the enzymatic reaction are whether embedded in the structure.

Supplementary Information The online version contains supplementary material available at https://doi. org/10.1007/s11144-021-02139-w.

Acknowledgements This work was supported by the National Research, Development and Innovation Office of Hungary (K131425 and K119795) and the NRDI Fund (TKP2020 IES, Grant No. BME-IENAT) based on the charter of bolster issued by the NRDI Office under the auspices of the Ministry for Innovation and Technology.

Funding Open access funding provided by Budapest University of Technology and Economics.

Open Access This article is licensed under a Creative Commons Attribution 4.0 International License, which permits use, sharing, adaptation, distribution and reproduction in any medium or format, as long as you give appropriate credit to the original author(s) and the source, provide a link to the Creative Commons licence, and indicate if changes were made. The images or other third party material in this article are included in the article's Creative Commons licence, unless indicated otherwise in a credit line to the material. If material is not included in the article's Creative Commons licence and your intended use is not permitted by statutory regulation or exceeds the permitted use, you will need to obtain permission directly from the copyright holder. To view a copy of this licence, visit http://creativecommons.org/licen ses/by/4.0/. 


\section{References}

1. Horváth AK, Nagypál I (2015) Classification of clock reactions. ChemPhysChem 16:588-594. https://doi.org/10.1002/cphc.201402806

2. Lente G, Bazsa G, Fábián I (2007) What is and what isn’t a clock reaction? New J Chem 31:1707. https://doi.org/10.1039/B708846A

3. Limpanuparb T, Ruchawapol C, Sathainthammanee D (2019) Clock reaction revisited: catalyzed redox substrate-depletive reactions. J Chem Educ 96:812-818. https://doi.org/10.1021/acs.jchem ed. $8 \mathrm{~b} 00547$

4. Landolt H (1886) Ueber die Zeitdauer der Reaction zwischen Jodsäure und schwefliger Säure. Ber Dtsch Chem Ges 19:1317-1365

5. Heuser T, Steppert AK, Molano LC, Zhu B, Walther A (2015) Generic concept to program the time domain of self-assemblies with a self-regulation mechanism. Nano Lett 15:2213-2219. https://doi.org/10.1021/n15039506

6. Heinen L, Walther A (2015) Celebrating Soft Matter's 10th anniversary: approaches to program the time domain of self-assemblies. Soft Matter 11:7857-7866. https://doi.org/10.1039/C5SM0 $1660 \mathrm{~F}$

7. Tóth-Szeles E, Horváth J, Holló G, Szúcs R, Hideyuki N, Lagzi I (2017) Chemically coded timeprogrammed self-assembly. Mol Syst Des Eng 2:274-282. https://doi.org/10.1039/C7ME00020K

8. Tóth-Szeles E, Medveczky Z, Holló G, Horváth J, Szúcs R, Hideyuki N, Lagzi I (2018) pH mediated kinetics of assembly and disassembly of molecular and nanoscopic building blocks. React Kinet Mech Cat 123:323-333. https://doi.org/10.1007/s11144-017-1312-X

9. Riedel S, Schweizer T, Smith-Mannschott K, Dufresne ER, Panzarasa G (2021) Supramolecular gelation controlled by an iodine clock. Soft Matter 17:1189-1193. https://doi.org/10.1039/ D0SM02285C

10. Hu G, Pojman JA, Scott SK, Wrobel MM, Taylor AF (2010) Base-catalyzed feedback in the urea-urease reaction. J Phys Chem B 114:14059-14063. https://doi.org/10.1021/jp106532d

11. Bubanja IN, Bánsági T, Taylor AF (2018) Kinetics of the urea-urease clock reaction with urease immobilized in hydrogel beads. React Kinet Mech Cat 123:177-185. https://doi.org/10.1007/ s11144-017-1296-6

12. Yang D, Fan J, Cao F, Deng Z, Pojman JA, Ji L (2019) Immobilization adjusted clock reaction in the urea-urease- $\mathrm{H}^{+}$reaction system. RSC Adv 9:3514-3519. https://doi.org/10.1039/C8RA0 9244C

13. Heuser T, Weyandt E, Walther A (2015) Biocatalytic feedback-driven temporal programming of self-regulating peptide hydrogels. Angew Chem Int Edit 54:13258-13262. https://doi.org/10.1002/ anie. 201505013

14. Panja S, Adams DJ (2021) Urea-urease reaction in controlling properties of supramolecular hydrogels: pros and cons. Chem-Eur J 27:8928-8939. https://doi.org/10.1002/chem.202100490

15. Jee E, Bánsági T, Taylor AF, Pojman JA (2016) Temporal control of gelation and polymerization fronts driven by an autocatalytic enzyme reaction. Angew Chem Int Ed 55:2127-2131. https://doi. org/10.1002/anie.201510604

16. Fan X, Walther A (2021) Autonomous transient $\mathrm{pH}$ flips shaped by layered compartmentalization of antagonistic enzymatic reactions. Angew Chem Int Ed 60:3619-3624. https://doi.org/10.1002/anie. 202009542

17. Miele Y, Holló G, Lagzi I, Rossi F (2021) Effect of the membrane composition of giant unilamellar vesicles on their budding probability: a trade-off between elasticity and preferred area difference. Life 11:634. https://doi.org/10.3390/life11070634

18. Holló G, Miele Y, Rossi F, Lagzi I (2021) Shape changes and budding of giant vesicles induced by an internal chemical trigger: an interplay between osmosis and $\mathrm{pH}$ change. Phys Chem Chem Phys 23:4262-4270. https://doi.org/10.1039/D0CP05952H

19. Miele Y, Medveczky Z, Holló G, Tegze B, Derényi I, Hórvölgyi Z, Altamura E, Lagzi I, Rossi F (2020) Self-division of giant vesicles driven by an internal enzymatic reaction. Chem Sci 11:32283235. https://doi.org/10.1039/C9SC05195C

20. Furukawa H, Cordova KE, O'Keeffe M, Yaghi OM (2013) The chemistry and applications of metalorganic frameworks. Science 341:1230444. https://doi.org/10.1126/SCIENCE.1230444

21. Gascon J, Corma A, Kapteijn F, Llabrés i Xamena FX (2014) Metal organic framework catalysis: Quo vadis? ACS Catal 4:361-378. https://doi.org/10.1021/cs400959k 
22. Rosi NL, Eckert J, Eddaoudi M, Vodak DT, Kim J, O’Keeffe M, Yaghi OM (2003) Hydrogen storage in microporous metal-organic frameworks. Science 300:1127-1129. https://doi.org/10.1126/ science. 1083440

23. Adams R, Carson C, Ward J, Tannenbaum R, Koros W (2010) Metal organic framework mixed matrix membranes for gas separations. Micropor Mesopor Mat 131:13-20. https://doi.org/10.1016/j. micromeso.2009.11.035

24. Campbell M, Dincă M (2017) Metal-organic frameworks as active materials in electronic S sensor devices. Sensors 17:1108. https://doi.org/10.3390/s17051108

25. Han S, Wei Y, Valente C, Lagzi I, Gassensmith JJ, Coskun A, Stoddart F, Grzybowski BA (2010) Chromatography in a single metal-organic framework (MOF) crystal. J Am Chem Soc 132:1635816361. https://doi.org/10.1021/ja1074322

26. Zheng H, Zhang Y, Liu L, Wan W, Guo P, Nyström AM, Zou X (2016) One-pot synthesis of metalorganic frameworks with encapsulated target molecules and their applications for controlled drug delivery. J Am Chem Soc 138:962-968. https://doi.org/10.1021/jacs.5b11720

27. He M, Yao J, Liu Q, Wang K, Chen F, Wang H (2014) Facile synthesis of zeolitic imidazolate framework-8 from a concentrated aqueous solution. Micropor Mesopor Mat 184:55-60. https://doi. org/10.1016/j.micromeso.2013.10.003

28. Choi HS, Lee SJ, Bae YS, Choung SJ, Im SH, Kim J (2015) Scalable continuous solvo-jet process for ZIF-8 nanoparticles. Chem Eng J 266:56-63. https://doi.org/10.1016/j.cej.2014.12.068

29. Kolmykov O, Commenge JM, Alem H, Girot E, Mozet K, Medjahdi G, Schneider R (2017) Microfluidic reactors for the size-controlled synthesis of ZIF-8 crystals in aqueous phase. Mater Design 122:31-41. https://doi.org/10.1016/j.matdes.2017.03.002

30. Liang W, Wied P, Carraro F, Sumby CJ, Nidetzky B, Tsung CK, Falcaro P, Doonan CJ (2021) Metal-organic framework-based enzyme biocomposites. Chem Rev 121:1077-1129. https://doi.org/ 10.1021/acs.chemrev.0c01029

31. Lee YR, Jang MS, Cho HY, Kwon HJ, Ahn WS (2015) ZIF-8: A comparison of synthesis methods. Chem Eng J 271:276-280. https://doi.org/10.1016/j.cej.2015.02.094

32. Pan Y, Liu Y, Zeng G, Zhao L, Lai Z (2011) Rapid synthesis of zeolitic imidazolate framework-8 (ZIF-8) nanocrystals in an aqueous system. Chem Commun 47:2071. https://doi.org/10.1039/ C0CC05002D

33. Chen B, Yang Z, Zhu Y, Xia Y (2014) Zeolitic imidazolate framework materials: recent progress in synthesis and applications. J Mater Chem A 2:16811-16831. https://doi.org/10.1039/C4TA02984D

34. Li K, Miwornunyuie N, Chen L, Jingyu H, Amaniampong PS, Koomson DA, Ewusi-Mensah D, Xue W, Li G, Lu H (2021) Sustainable application of ZIF-8 for heavy-metal removal in aqueous solutions. Sustainability 13:984. https://doi.org/10.3390/su13020984

35. Wang Q, Sun Y, Li S, Zhang P, Yao Q (2020) Synthesis and modification of ZIF-8 and its application in drug delivery and tumor therapy. RSC Adv 10:37600-37620. https://doi.org/10.1039/D0RA0 $7950 \mathrm{~B}$

36. Zheng B, Sant M, Demontis P, Suffritti GB (2012) Force field for molecular dynamics computations in flexible ZIF-8 framework. J Phys Chem C 116:933-938. https://doi.org/10.1021/jp209463a

37. Carter EL, Flugga N, Boer JL, Mulrooney SB, Hausinger RP (2009) Interplay of metal ions and urease. Metallomics 1:207. https://doi.org/10.1039/b903311d

38. Larsen KS, Auld DS (1989) Carboxypeptidase A: mechanism of zinc inhibition. Biochemistry 28:9620-9625. https://doi.org/10.1021/bi00451a012

39. Yang Z, Liu S, Zheng D, Feng S (2006) Effects of cadium, zinc and lead on soil enzyme activities. J Environ Sc 18:1135-1141. https://doi.org/10.1016/S1001-0742(06)60051-X

40. http://www.math.pitt.edu/ bard/xpp/xpp.html

41. Hoops S, Sahle S, Gauges R, Lee C, Pahle J, Simus N, Singhal M, Xu L, Mendes P, Kummer U (2006) COPASI-a COmplex PAthway SImulator. Bioinformatics 22:3067-3074. https://doi.org/10. 1093/bioinformatics/btl485

42. Krajewska B (2009) Ureases I. functional, catalytic and kinetic properties: a review. J Mol Catal B-Enzym 59:9-21. https://doi.org/10.1016/j.molcatb.2009.01.003

43. Li Y, Xu L, Duan M, Zhang B, Wang Y, Guan Y, Wu J, Jing C, You Z (2019) Syntheses, characterization, crystal structures and Jack bean urease inhibitory activities of $\mathrm{Zn}^{\mathrm{II}}, \mathrm{Co}^{\mathrm{II} / \mathrm{III}}$ and $\mathrm{Ni}^{\mathrm{II}}$ complexes derived from reduced Schiff base ligand. Polyhedron 166:146-152. https://doi.org/10.1016/j. poly.2019.03.051

44. Park IS, Hausinger RP (1996) Metal ion interactions with urease and ureD-urease apoproteins. Biochemistry 35:5345-5352. https://doi.org/10.1021/bi952894j 
45. Shaw WHR, Raval DN (1961) The inhibition of urease by metal ions at pH 8.9. J Am Chem Soc 83:3184-3187. https://doi.org/10.1021/ja01476a004

46. Liang K, Coghlan CJ, Bell SG, Doonan C, Falcaro P (2016) Enzyme encapsulation in zeolitic imidazolate frameworks: a comparison between controlled co-precipitation and biomimetic mineralisation. Chem Commun 52:473-476. https://doi.org/10.1039/C5CC07577G

47. Liang K, Ricco R, Doherty CM, Styles MJ, Bell S, Kirby N, Mudie S, Haylock D, Hill AJ, Doonan CJ, Falcaro P (2015) Biomimetic mineralization of metal-organic frameworks as protective coatings for biomacromolecules. Nat Commun 6:7240. https://doi.org/10.1038/ncomms8240

48. Liang X, Li Q, Shi Z, Bai S, Li Q (2020) Immobilization of urease in metal-organic frameworks via biomimetic mineralization and its application in urea degradation. Chin J Chem Eng 28:2173-2180. https://doi.org/10.1016/j.cjche.2020.01.014

49. Bhattacharya A, Naik SN, Khare SK (2019) Efficacy of ureolytic Enterobacter cloacae EMB19 mediated calcite precipitation in remediation of Zn (II). J Environ Sci Heal A 54:536-542. https:// doi.org/10.1080/10934529.2019.1567184

Publisher's Note Springer Nature remains neutral with regard to jurisdictional claims in published maps and institutional affiliations.

\section{Authors and Affiliations}

\section{Norbert Német ${ }^{1} \cdot$ Ylenia Miele $^{2} \cdot$ Gábor Shuszter $^{3}$ D Eszter L. Tóth ${ }^{1}$. János Endre Maróti ${ }^{4} \cdot$ Péter János Szabó ${ }^{4} \cdot$ Federico Rossi $^{5}$ (D) $\cdot$ István Lagzi ${ }^{1,6}$ (D)}

1 Department of Physics, Budapest University of Technology and Economics, Budafoki út 8, 1111 Budapest, Hungary

2 Department of Chemistry and Biology “A. Zambelli”, University of Salerno, Via Giovanni Paolo II 132, 84084 Fisciano, SA, Italy

3 Department of Physical Chemistry and Materials Science, University of Szeged, Rerrich Béla tér 1, 6720 Szeged, Hungary

4 Department of Materials Science and Engineering, Budapest University of Technology and Economics, Budapest, Hungary

5 Department of Earth, Environmental and Physical Sciences-DEEP Sciences, University of Siena, Pian dei Mantellini 44, 53100 Siena, Italy

6 MTA-BME Condensed Matter Physics Research Group, Budafoki út 8, 1111 Budapest, Hungary 